\title{
Comparison of Different Extraction Techniques of Zingiber officinale Essential Oil
}

\author{
Edgar Teixeira de Souza Junior ${ }^{1}$ \\ https://orcid.org/0000-0003-4411-8046 \\ Leandro Martins Siqueira ${ }^{1}$ \\ https://orcid.org/0000-0001-8783-0127
}

\section{Rafael Nolibos Almeida ${ }^{1}$}

https://orcid.org/0000-0002-5792-5392

\section{Aline Machado Lucas ${ }^{1}$}

https://orcid.org/0000-0002-6154-8745

\section{Caroline Garcia Finkler da Silva ${ }^{1}$}

https://orcid.org/0000-0002-0665-4975

\section{Eduardo Cassel ${ }^{1}$}

https://orcid.org/0000-0001-8843-0694

\section{Rubem Mário Figueiró Vargas ${ }^{1^{*}}$}

https://orcid.org/0000-0003-2696-8581 1Pontifical Catholic University of Rio Grande do Sul, Politechnic School, Unit Operations Laboratory, Porto Alegre, Rio
Grande do Sul, Brazil.

Received: 2019.04.03; Accepted: 2020.02.07.

*Correspondence: rvargas@pucrs.br; Tel.: +55-51-993064077 (R.M.F.V.)

\section{HIGHLIGHTS}

- Ginger essential oil was extracted by SFE, SD and HD, modelling was also performed.

- Different pressures (SD and SFE) and water volumes (HD) were investigated.

- The extraction products were analyzed by GC/MS.

- PCA was performed, geranial and a-zingiberene have the greatest covariance.

Abstract: This study aims to find the best conditions for the extraction of Zingiber officinale essential oil using the supercritical fluid extraction (SFE), steam distillation (SD) and hydrodistillation (HD) techniques, regarding the maximum oil yield. For the HD technique is evaluated the best ratio between plant mass and water volume and for SFE and SD the pressure condition was investigated. Principal Component Analysis (PCA) was used to evaluate the similarity between the composition of the essential oil in different pressures and extraction methods. The experimental extraction curve was plotted and three different mathematical models were used to fit the data for SD and SFE methods, obtaining the relevant mass transfer parameters. The essential oil compounds were identified by gas chromatography coupled with mass spectrometry (GC-MS), being $\alpha$ zingiberene the main component with different contents (from 11.9 to $28.9 \%$ ). The best condition for the SFE 
was 100 bar, $40{ }^{\circ} \mathrm{C}\left(0.0508 \mathrm{~g}_{\text {oil }} / \mathrm{g}_{\text {plant }}\right)$ with $19.34 \%$ of $\alpha$-zingiberene; for the $\mathrm{SD}, 3$ bar $\left(133{ }^{\circ} \mathrm{C}\right)(0.00616$ $\left.\mathrm{g}_{\text {oil }} / \mathrm{g}_{\text {plant }}\right)$ with $28.9 \%$ of $\alpha$-zingiberene; and HD, the volume of $750 \mathrm{~mL}\left(0.006988 \mathrm{~g}_{\text {oil }} / \mathrm{g}_{\text {plant }}\right)$ with $15.70 \%$ of $\alpha$ zingiberene, all measured on a dry basis.

Keywords: Zingiber officinale, supercritical fluid extraction, steam distillation, hydrodistillation, mathematical modeling.

\section{INTRODUCTION}

Ginger (Zingiber officinale) is an herbaceous and perennial plant, from the Zingiberaceae family, which its rhizome is widely used in the food and pharmaceutical industry [1]. The plant originates in Asian, India being its biggest producer in 2017 [2]. It has several known properties such as anti-inflammatory activity [3], antibacterial activity [4] and hypoglycemic activity [5], among others. The anticancer properties of certain ginger compounds such as 6-gingerol and 6-shogaol have been studied and demonstrated to be effective against lung cancers [6], ovarian cancers [7], liver [8] and skin cancers [9].

Ginger rhizomes present a volatile oil composed of monoterpenes (5\%), sesquiterpenes (65\%) and oxygenated compounds (30\%). The latter, found in the oil-resin [10]. These compounds are responsible for its characteristic taste, whose main compound is the $\alpha$-zingiberene sesquiterpene.

Natural products can be obtained by different extraction techniques. The steam distillation (SD) process is a common method for essential oil extraction; however, it has some disadvantages, such as the use of high temperatures, which can degrade thermolabile compounds, residual solvent in the product and solvent waste in the process. As advantages, one can cite the low cost of the process, compared to more sophisticated extraction methods. In contrast, supercritical fluid extraction (SFE) can be used as an alternative, which uses non-toxic solvents such as carbon dioxide and promotes a complete separation between the solvent and the product; however, implementation costs are still a barrier to this type of process [11-15].

Hydrodistillation (HD) is also a traditional method in obtaining essential oils, it uses water as solvent, which is an advantage as it does not leave toxic residues at the end of the extraction, but the Clevenger apparatus needs adaptation in order to obtain oils denser than water when used a laboratory scale due to the recirculation process in this Clevenger apparatus. One of its disadvantages is the potential hydrolysis of some components, since the solvent remains in direct contact with the vegetal material during the extraction, tampering the final extract. Therefore, different extraction methods lead to products with different compositions, mainly because of solvent-extract interactions [16].

The Principal Component Analysis (PCA) performs a statistical comparison between different datasets and is widely used in the case of percentage area of essential oils composition when extracted under different conditions [17]. In this work the comparison between the different extracts, characterized by GC-MS, is made using this tool in order to compare the products coming from the different methods.

The mathematical modeling of the extraction process is an important step for its scale-up. There are a large variety of models that can describe solid-liquid extractions such as power law models that have extensive use in adsorption processes [18], or models based on diffusive mechanisms with association to phase equilibria, such as described by Crank [19]. Another option is the use of differential mass balances for each phase that generate differential equations solved numerically by means of suitable techniques [20]. In this work three different techniques of extraction, SD, SFE and HD were investigated, aiming to maximize the yield of ginger essential oil. Three different models were used to adjust the experimental data: a kinetic model based on a power law, a model related based on diffusion mechanism and a model constructed by a differential balance in the extraction bed.

\section{MATERIAL AND METHODS}

\section{Sample preparation}

Ginger rhizomes were bought in Porto Alegre and originally grown at Morrinhos do Sul - Rio Grande do Sul, Brazil (-29.30, -49.92). The rhizomes of Zingiber officinale in natura were cut into irregular pieces without removing their bark. The wet plant was grounded using a knife mill and a sample was collected to quantify its humidity (thermo-gravimetric balance - BEL Engineering) and its thickness. 


\section{Extraction methods}

The supercritical fluid extractions (SFE) were carried out on the pilot-scale equipment represented in a schematic diagram (Figure 1). The pilot unit has a high-pressure pump (Maximator-G35) for carbon-dioxide (P1), a storage cylinder of $\mathrm{CO}_{2}(\mathrm{C} 1)$, two pre- heaters (HE1, $\left.\mathrm{HE} 2\right)$, a system to measure the $\mathrm{CO}_{2}$ flow and two vessels for separation (VS1, VS2), which are made of glass (IImabol TGI Boro 3.3) [21]. The supercritical fluid extractions were performed in an extraction vessel (Waters) with $500 \mathrm{~mL}$ capacity, $6.3 \mathrm{~cm}$ diameter and $19 \mathrm{~cm}$ height. The investigated conditions were determined according to previous works range in order to obtain the volatile extracts using the SFE methodology: four different pressures (80,90, 100 and 110 bar) at $40{ }^{\circ} \mathrm{C}$, with a $1000 \mathrm{~g} \cdot \mathrm{h}^{-1} \mathrm{CO}_{2}$ flow rate [22-24] and $0.2 \mathrm{~kg}$ of ginger rhizome.

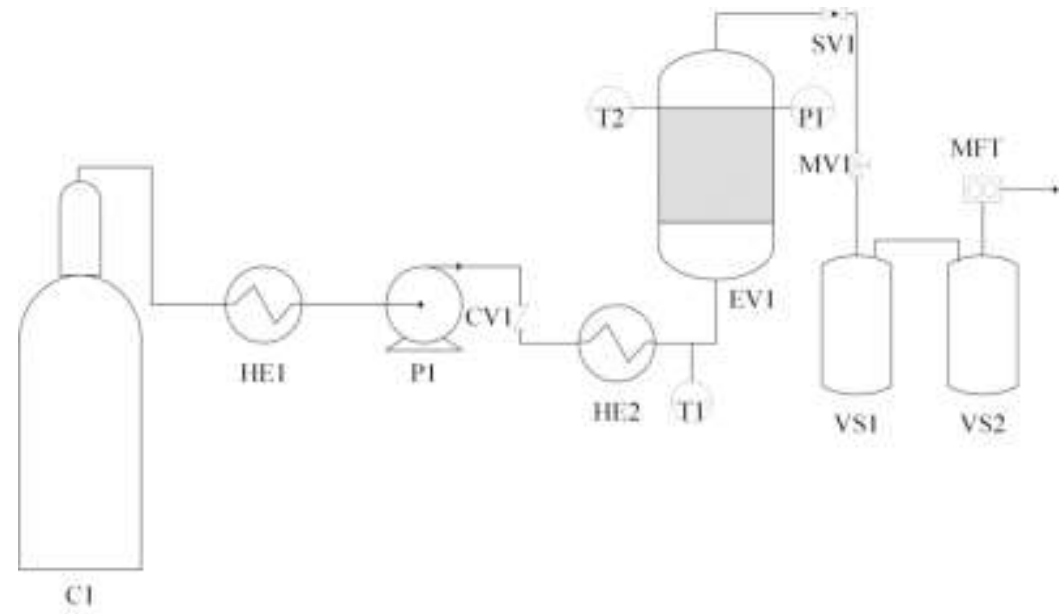

Figure 1. Supercritical extraction experimental apparatus: $\mathrm{C}-\mathrm{CO} 2$ cylinder, $\mathrm{HE}$ - heat exchanger, $\mathrm{CV}$ - check valve, $\mathrm{P} 1$ - CO2 high pressure pump, EV - extraction vessel, $\mathrm{T}$ - temperature transmitter, $\mathrm{P}$ - pressure transmitter, VS separation vessel, MFT - mass flow transmitter, SV - Shut-off valve.

For the highest essential oil yield, the experimental extraction curve, the plot of the cumulated extract versus the extraction time, was built in triplicate aiming to enable the mathematical modeling. The extracts were collected with the time interval of $10 \mathrm{~min}$. The experimental extraction curves, yield versus time, were fulfilled when the essential oil volume did not vary after three consecutive measurements.

The steam distillation extractions were performed on pilot-scale equipment, which is represented in a schematic diagram as shown in Figure 2. The equipment has a boiler (B1) with a capacity of $20 \mathrm{~L}$ of solvent (water) and a power source of $2 \mathrm{~kW}$, with level sensors (upper and lower), measuring pressure and temperature [25].

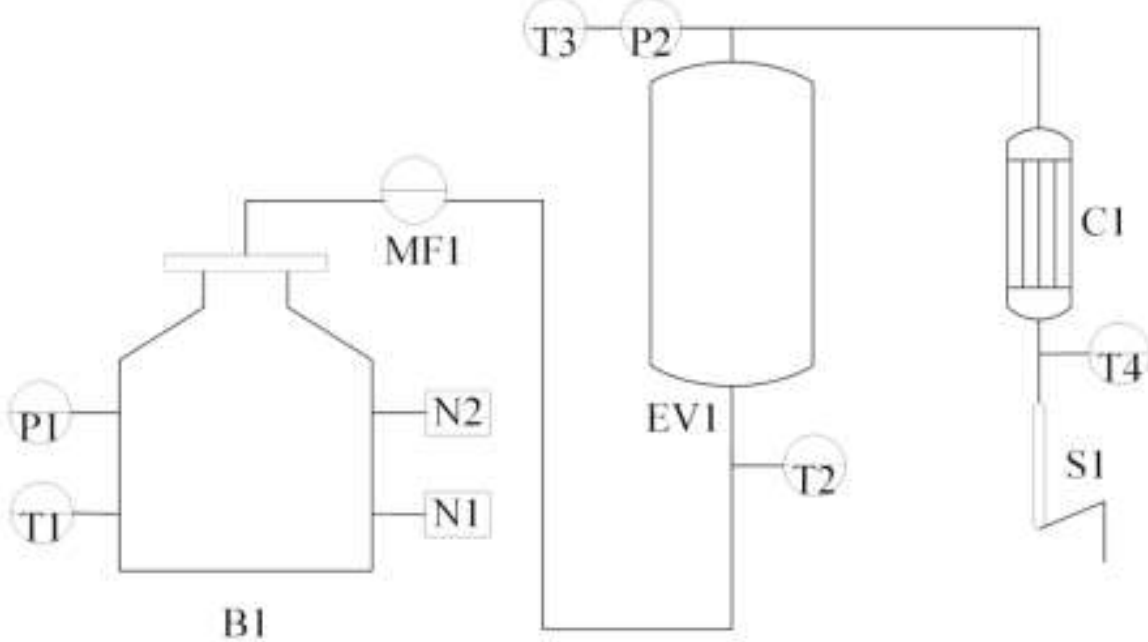

Figure 2. Steam distillation apparatus: $\mathrm{B}$ - boiler, $\mathrm{EV}$ - extraction vessel, $\mathrm{C}$ - condenser, $\mathrm{S}$ - separator, $\mathrm{T}$ - temperature transmitter, $\mathrm{P}$ - pressure transmitter, MF - flow measure, $\mathrm{N}$ - level switch. 
The steam distillation process was performed with the same plant material submitted to the procedure described in sample preparation. In this case, the ginger mass was $2000 \mathrm{~g}$ and the extraction vessel used (EV1) has $9.4 \mathrm{~L}$ capacity, $31.3 \mathrm{~cm}$ height and $19.3 \mathrm{~cm}$ diameter. The extractions were conducted in three different absolute pressures (1,2, and 3 bar). The extraction curve, defined as the yield versus time, was determined experimentally collecting the volume of essential oil every $5 \mathrm{~min}$. The extraction step is completed when the volume change of essential oil in the separator is not observed by three consecutive measurements. The experiments were performed in triplicate for each extraction condition.

The essential oil specific mass was determined through the mass measure of $1 \mathrm{~mL}$ of the oil using an analytical balance (Marte AW220 $\mathrm{e}= \pm 0.0001 \mathrm{~g}$ ). This procedure was performed in triplicate. The plant specific mass was determined by a pycnometer (Quantachrome MVP-6DL) analysis.

The hydrodistillation process was carried out with the sample previously cut and dried for $24 \mathrm{~h}$ at $30^{\circ} \mathrm{C}$ to be easier milled. The process consists of $50 \mathrm{~g}$ of the prepared material in a $1 \mathrm{~L}$ flask, which was connected to a Clevenger apparatus. The flask is heated using a heating blanket until boiling, the generated steam then arrives at condenser which is connected to a continuously flowing water stream, the vapor is condensed, and the oil obtained is removed by density difference with water.

\section{GC Analysis}

Zingiber officinale essential oils were dehydrated using anhydrous sodium sulphate $\left(\mathrm{Na}_{2} \mathrm{SO}_{4}-\mathrm{Synth}\right)$ and diluted in cyclohexane (1:2) (Merck). The chemical composition was determined using a gas chromatograph equipped with a mass spectrometer (Hewlett Packard e Agilent system GC/MS model 7890A and mass detector $5975 \mathrm{C})$. The carrier gas was helium $\left(0.8 \mathrm{~mL}^{\mathrm{min}}{ }^{-1}\right)$, injector temperature was $250{ }^{\circ} \mathrm{C}$, volume injected was $0.2 \mu \mathrm{L}$, split mode with split ratio of 1:55. The capillary column was HP-5MS (Hewlett Packard e Agilent, $5 \%$ phenyl methyl silox, $30 \mathrm{~m} \times 250 \mu \mathrm{m}$ of internal diameter with $0.25 \mu \mathrm{m}$ of film thickness). The temperature programming was $60^{\circ} \mathrm{C}(8 \mathrm{~min}), 60^{\circ} \mathrm{C}-180^{\circ} \mathrm{C}, 3^{\circ} \mathrm{C} / \mathrm{min}, 180^{\circ} \mathrm{C}(1 \mathrm{~min}), 180^{\circ} \mathrm{C}-250^{\circ} \mathrm{C}$, $20^{\circ} \mathrm{C} / \mathrm{min}, 250^{\circ} \mathrm{C}(10 \mathrm{~min})$.

The components of the essential oils were identified by comparison of their Retention Index (RIs) on the column, determined in relation to a homologous series of n-alkanes, with those from pure standards or reported in literature. Comparison of fragmentation patterns in the mass spectra with those stored on the GCMS databases was also performed [26].

\section{Mathematical modeling}

Three mathematical models were used to simulate the supercritical fluid extraction and steam distillation of Zingiber officinale, based on different approaches. The first model (Model 1) is based in a power law equation [18]. In order to describe the extraction kinects the equation becomes as showed in Equation 1.

$$
\frac{\mathrm{dM}}{\mathrm{dt}}=\mathrm{k}(\Delta \mathrm{M})^{\mathrm{n}}=\mathrm{k}\left(\mathrm{M}_{\infty}-\mathrm{M}\right)^{\mathrm{n}}
$$

Where $M_{\infty}$ ( $g_{\text {extract }}$ ) is the maximum oil mass (the essential oil mass at an infinite time), $M$ is the oil mass in a determined time, $\mathrm{n}$ is the model order and $\mathrm{k}$ is the extraction rate constant $\left(\mathrm{s}^{-1}\right)$. Assuming the beginning of the extraction time being equal to zero, the solute concentration present in the solvent is zero. Then the first order model $(n=1)$ is obtained through Equation 1, resulting in Equation 2.

$$
\mathrm{M}=\mathrm{M}_{\infty}\left(1-\exp ^{-\mathrm{kt}}\right)
$$

The second mass transfer model (Model 2) used is derived from the Fick's second law diffusion law for a slab geometry in a finite-dimensional medium under conditions of negligible surface resistance, considering uniform initial concentration, mass transfer in a system with symmetry in relation to midpoint and constant surface concentration. The diffusion coefficient is considered constant during the extraction process. The sample during the extraction is considered a plate with half the thickness equal to $L(\mathrm{~mm})$. The unidimensional diffusion is assumed. This model has solution presented by Crank [19] and is presented in Equation 3.

$$
\frac{M}{M_{\infty}}=1-\frac{8}{\pi^{2}} \sum_{n=0}^{\infty} \frac{1}{(2 n+1)^{2}} \exp \left\{-\frac{\left(2 n+1^{2}\right) \pi^{2} D t}{4 L^{2}}\right\}
$$


Where $M$ and $M_{\infty}$ are the amount of solute removed in a determined time and the correponding quantity after infinite time (maximum mass obtained in the extraction), respectively, $D$ is the diffusivity of the solute inside the particle $\left(\mathrm{m}^{2} \cdot \mathrm{s}^{-1}\right), \mathrm{t}$ is the extraction time $(\mathrm{s})$.

The third model (Model 3) used in this work was based in the model developed by Reverchon [27]. The model consists of one-dimensional mass balance for the extract, assuming the hypothesis of a linear behavior for the solid-fluid phase equilibrium. Two independent variables, time $(t)$ and the fixed bed height $(z)$ was considered, and the radial dispersion along the column is negligible. The mass balance is given below (Equations 4 and 5) [28].

$$
\begin{gathered}
\frac{\partial C(z, t)}{\partial t}=-v \frac{\partial C(z, t)}{\partial z}-\frac{1-\varepsilon}{\varepsilon} \rho_{s} \frac{\partial q(z, t)}{\partial t} \\
\frac{\partial q(z, t)}{\partial t}=-k_{T M}[q(z, t)-K \cdot C(z, t)]
\end{gathered}
$$

The concentration of the essential oil in the vapor phase is given by the function $C(z, t)$ and the concentration in the aromatic plant is described by the $q(z, t)$ function. Where $v$ is the interstitial fluid velocity; $\varepsilon$ is the bed porosity; $\mathrm{k}_{\mathrm{TM}}$ is the internal mass transfer coefficient; $\rho_{\mathrm{s}}$ is the specific mass of the aromatic plant and $\mathrm{K}$ is the equilibrium constant between the phases. The model also considers some initial and boundary conditions: $q(z, 0)=q_{0}$ and $C(z, 0)=0, q_{0}$ is defined as the total amount of extract in the solid phase and the $C(z, 0)=0$ as a boundary condition. The linear behavior for the solid-fluid equilibrium is expressed by $q^{*}(z, t)=$ $\mathrm{K} \cdot \mathrm{C}(\mathrm{z}, \mathrm{t})$.

\section{RESULTS}

The average yield (dry basis) obtained through the experimental data acquired by the extractions is presented in Table 1. The average specific experimental mass of the essential oil obtained was $\rho_{\text {oil }}=0.87$ g. $\mathrm{cm}^{-3}$, the plant specific mass determined by the use of the pycnometer was $\rho_{\text {plant }}=1.24 \mathrm{~g} \cdot \mathrm{cm}^{-3}$ and its average thickness value was $1.74 \cdot 10^{-4} \mathrm{~m}$.

Table 1. SD, SFE and HD yield results.

\begin{tabular}{ccc}
\hline Extraction method & Pressure $(\mathbf{b a r})$ & Global yield $\left(\mathbf{g}_{\mathrm{EO}} / \mathbf{1 0 0} \mathbf{g}\right.$ dried plant) \\
\hline \multirow{2}{*}{$\mathrm{SD}^{1}$} & 1 & 0.25 \\
& 2 & 0.25 \\
& 3 & 0.62 \\
\hline \multirow{2}{*}{$\mathrm{SFE}^{2}$} & 80 & 3.30 \\
& 90 & 4.06 \\
& 100 & 5.08 \\
& 110 & 4.48 \\
\hline $\mathrm{HD}$ & Water volume $(\mathrm{mL})$ & Global yield $\left(\mathrm{g}_{\mathrm{EO}} / 100 \mathrm{~g}\right.$ dried plant $)$ \\
\cline { 2 - 3 } & 500 & 0.35 \\
& 750 & 0.69 \\
& 1000 & 0.52 \\
\hline
\end{tabular}

1 = saturated water vapor

2 = fluid temperature $40^{\circ} \mathrm{C}$

According to the proposed methodology, the mathematical modeling was performed, and the results are presented in Figures 3 and 4. The modeling was done for the highest yield extraction conditions ( 3 bar for SD and 100 bar for SFE). The values of the estimated parameters along with the determination coefficient (R2) for each method are presented in Table 2. 
Table 2. Parameters obtained through the modeling of supercritical fluid extraction (SFE) and steam distillation (SD) data.

\begin{tabular}{lccccccc}
\hline & \multicolumn{3}{c}{ Model 1 } & \multicolumn{3}{c}{ Model 2 } & \multicolumn{2}{c}{ Model 3 } \\
\hline & $\mathrm{k} \cdot 10^{4} \mathrm{~s}^{-1}$ & $\mathrm{R}^{2}$ & $\mathrm{D} \cdot 10^{13} \mathrm{~m}^{2} \cdot \mathrm{s}^{-1}$ & $\mathrm{R}^{2}$ & $\mathrm{~K} \cdot 10^{4} \mathrm{~m}^{3} \cdot \mathrm{kg}^{-1}$ & $\mathrm{kTM} \cdot 10^{4} \cdot \mathrm{s}^{-1}$ & $\mathrm{R}^{2}$ \\
\hline $\mathrm{SD}$ & 0.568 & 0.9904 & 1.04 & 0.9217 & 2.560 & 0.702 & 0.9863 \\
\hline SFE & 2.670 & 0.9809 & 5.73 & 0.9838 & 0.011 & 2.780 & 0.9768 \\
\hline
\end{tabular}

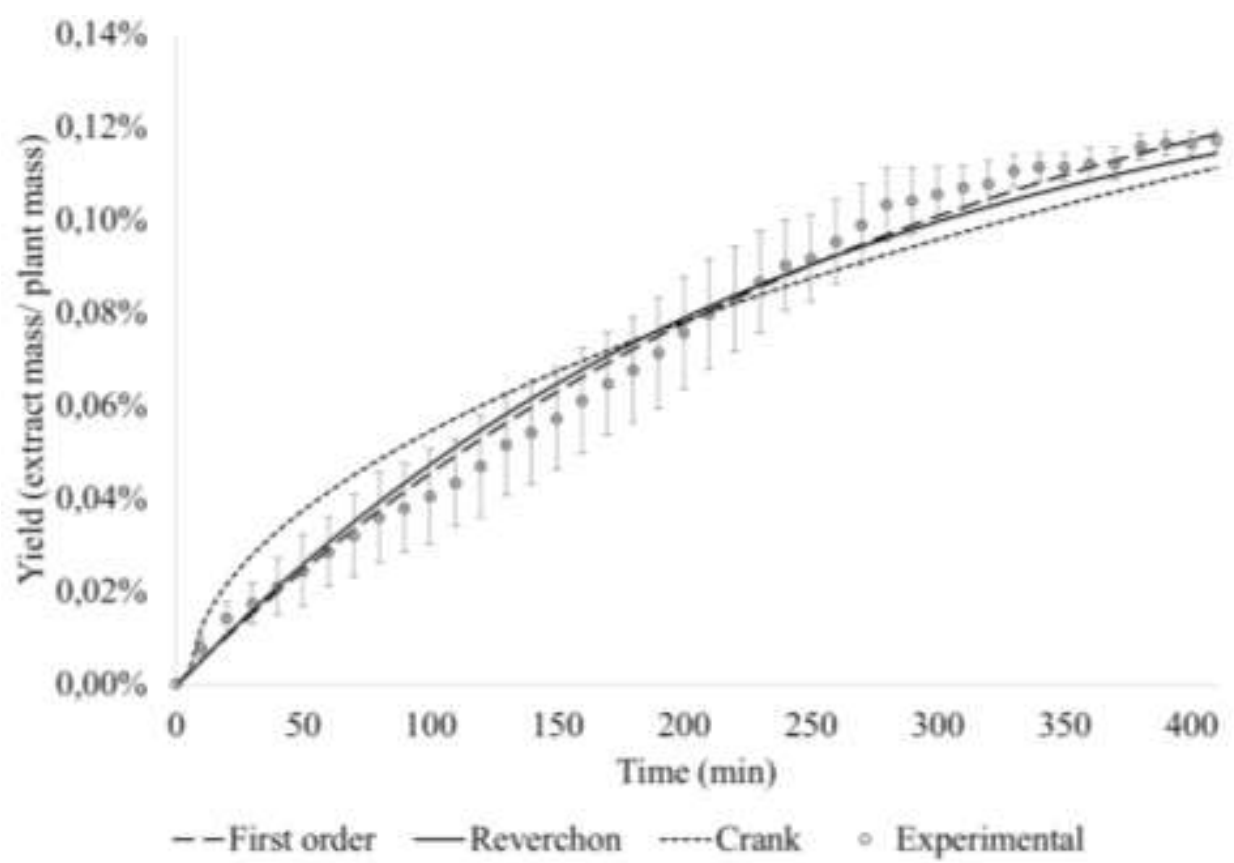

Figure 3. Steam distillation (yield curve vs. time at 3 bar and $406.15 \mathrm{~K}$ ).

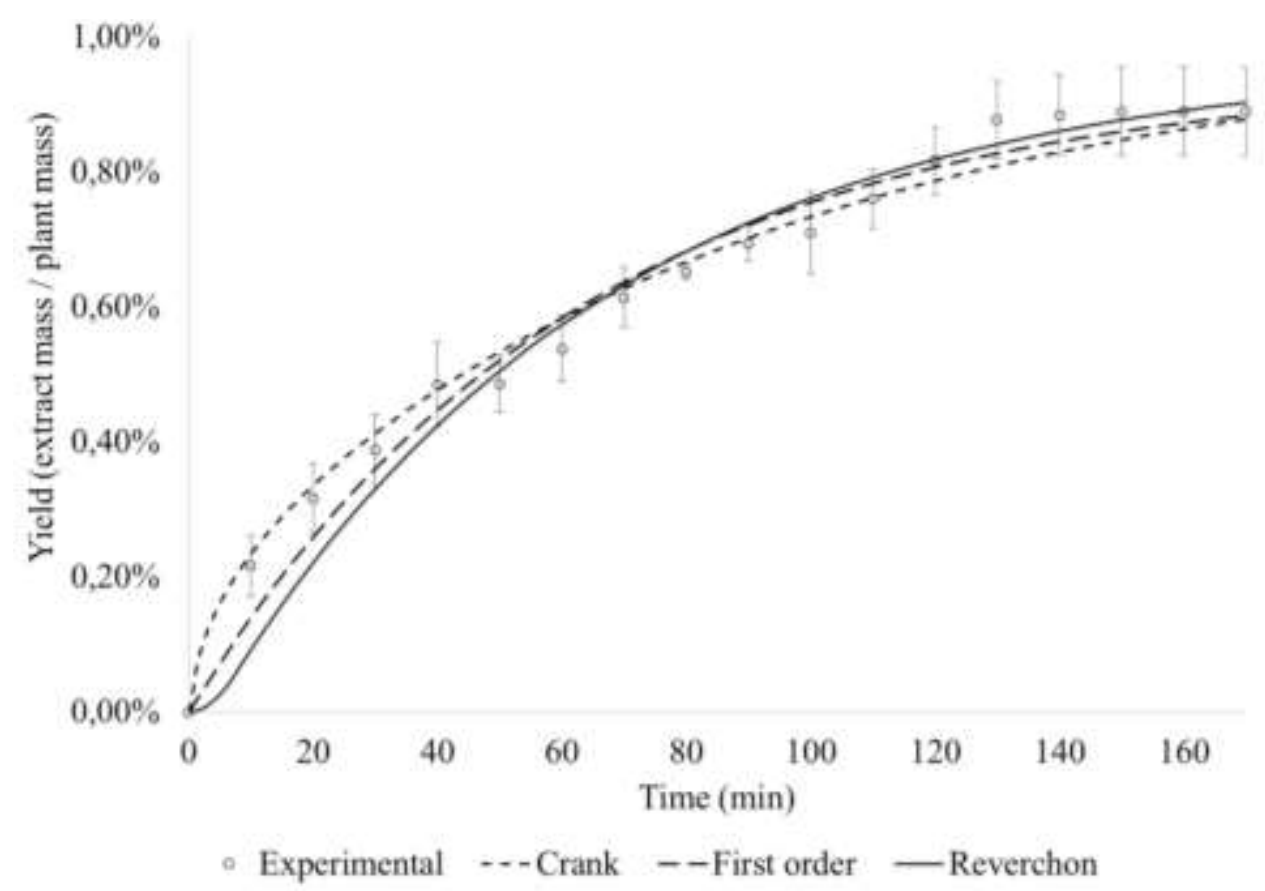

Figure 4. Supercritical fluid extraction (yield curve vs. time at 100 bar and $313.15 \mathrm{~K}$ ). 
Analysis of the Zingiber officinale essential oil

The major compounds identified in the Zingiber officinale essential oil are in accordance with those reported by Alhassane and Zhang 25. The full component list by GC-MS with their respective retention index, percentage area, for each method and condition studied is showed in Table 3. 
Table 3. Chemical composition of Zingiber officinale essential oil obtained by HD, SD and SFE at different extraction conditions.

\begin{tabular}{|c|c|c|c|c|c|c|c|c|c|c|c|}
\hline \multirow[b]{2}{*}{ Compounds $^{1}$} & \multirow[b]{2}{*}{$\mathbf{I R}^{2}$} & \multicolumn{2}{|c|}{$\mathrm{HD}^{3}$} & \multirow[b]{2}{*}{$\begin{array}{c}1000 \\
\mathrm{~mL}\end{array}$} & \multirow[b]{2}{*}{1 bar } & \multicolumn{2}{|l|}{$\mathrm{SD}^{3}$} & \multicolumn{2}{|c|}{ SFE $^{3}$} & \multirow[b]{2}{*}{100 bar } & \multirow[b]{2}{*}{110 bar } \\
\hline & & $500 \mathrm{~mL}$ & $750 \mathrm{~mL}$ & & & 2 bar & 3 bar & $\begin{array}{l}80 \\
\text { bar }\end{array}$ & 90 bar & & \\
\hline Hexanal & 802 & 0.12 & 0.05 & & & 0.07 & & & & & \\
\hline Heptanol & 900 & & 0.05 & 0.18 & & 0.14 & & 0.54 & 0.59 & 0.48 & \\
\hline Tricyclene & 916 & & & & 0.19 & 0.12 & 0.09 & & & & \\
\hline$\alpha$-Pinene & 926 & 1.37 & 0.66 & 1.35 & 3.01 & 2.14 & 1.64 & & 0.36 & & \\
\hline Camphene & 940 & 3.53 & 1.75 & 3.82 & 8.41 & 5.59 & 3.86 & 0.46 & 1.19 & & 0.91 \\
\hline$\beta$-Pinene & 969 & 0.32 & 0.16 & 0.31 & 0.13 & 0.05 & & & & & \\
\hline $\begin{array}{l}\text { Hepten-2-one (6- } \\
\text { methyl-5) }\end{array}$ & 983 & 0.31 & 0.12 & 0.17 & 0.69 & 0.48 & 0.23 & 0.6 & & & \\
\hline Myrcene & 987 & 0.77 & 0.38 & 0.76 & 1.7 & 1.17 & 0.89 & & & & \\
\hline a-Phellandrene & 1000 & 0.23 & 0.12 & 0.31 & 0.58 & 0.47 & 0.5 & & & & \\
\hline$\beta$-Phellandrene & 1025 & 2.75 & 1.45 & 3.9 & 7.35 & 5.94 & 3.6 & 2.08 & 3.15 & 1.09 & 3.41 \\
\hline 1.8-Cineole & 1027 & 2.48 & 0.57 & 1.67 & 2.53 & 3.23 & 0.68 & 2.72 & 2.49 & 1.48 & 3.06 \\
\hline$\gamma$-Terpinene & 1054 & & & & & 0.05 & & & & & \\
\hline Terpinolene & 1083 & & 0.55 & 1.71 & 0.44 & 0.34 & 0.29 & & & & \\
\hline 2-Nonanone & 1087 & & & & 0.15 & 0.17 & & & & & \\
\hline Linalool & 1097 & 0.32 & 0.23 & 0.45 & 0.32 & 0.54 & 0.25 & 0.81 & 0.62 & 0.57 & \\
\hline Nonanol & 1099 & & 0.07 & 0.18 & 0.2 & 0.29 & & 0.55 & 0.49 & & \\
\hline Camphor & 1141 & & & & & 0.06 & & & & & \\
\hline exo-Isocitral & 1140 & & & & 0.12 & 0.13 & & & & & \\
\hline Citronellal & 1150 & 0.27 & 0.21 & 0.51 & 0.62 & 0.34 & & & & & \\
\hline Borneol & 1160 & 0.38 & 0.61 & 1.36 & 0.34 & 1.04 & 0.1 & 2.07 & 1.34 & 1.26 & 1.39 \\
\hline Terpinen-4-ol & 1172 & 0.32 & 0.41 & 0.27 & 0.08 & 0.16 & & 0.35 & & & \\
\hline (E)-Isocitral & 1180 & 0.16 & 0.08 & 0.38 & 0.64 & 0.28 & & & & & \\
\hline$\alpha$-Terpineol & 1186 & 0.76 & 0.71 & 1.09 & 0.32 & 0.75 & 0.12 & 1.66 & 1.2 & 1.18 & 1.31 \\
\hline Myrtenal & 1195 & & & & & 0.03 & & & & & \\
\hline n-Decanal & 1201 & & & & & 0.09 & 0.13 & & & & \\
\hline Citronellol & 1227 & 0.99 & 0.83 & 1.06 & 0.71 & 0.89 & 0.41 & 1.18 & 1.77 & 1.75 & 1.82 \\
\hline
\end{tabular}




\begin{tabular}{|c|c|c|c|c|c|c|c|c|c|c|c|}
\hline Neral & 1239 & 4.61 & 3.49 & 7.53 & 5.42 & 3.79 & 0.79 & 8.28 & 6.95 & 7.08 & 7.75 \\
\hline Geraniol & 1253 & 1.13 & 0.75 & 0.73 & 0.5 & 0.78 & 0.38 & 4.85 & 4.38 & 4.59 & 5.28 \\
\hline Geranial & 1270 & 5.97 & 4.66 & 10.19 & 8.09 & 5.42 & 1.33 & 13.91 & 17.62 & 21.18 & 25.05 \\
\hline Bornyl acetate & 1281 & & & & 0.14 & 0.12 & & 0.69 & & & \\
\hline 2-Undecanone & 1290 & 0.24 & 0.21 & 0.37 & 0.4 & 0.47 & 0.22 & 1.04 & 0.85 & 0.83 & \\
\hline 2-Decanol & 1298 & & & & 0.08 & 0.09 & & & & & \\
\hline para-vinyl-Guaiacol & 1309 & & & & & & 0.1 & & & & \\
\hline$\delta$-Elemene & 1332 & & & & & 0.1 & 0.18 & & 0.56 & & \\
\hline Citronellyl Acetate & 1351 & & 0.13 & 0.15 & 0.17 & 0.14 & 0.13 & & & & \\
\hline Cyclosativene & 1360 & & & & & 0.07 & & & 3.39 & 2.58 & \\
\hline a-Copaene & 1369 & & 0.21 & 0.17 & 0.35 & 0.46 & 0.59 & 1.52 & & & \\
\hline Geranil Acetate & 1380 & 0.42 & 0.44 & 0.51 & 0.63 & 0.56 & & 0.48 & 0.62 & 0.81 & 1.15 \\
\hline$\beta$-Elemene & 1386 & 0.25 & 0.23 & & 0.27 & 0.64 & 1.01 & & 0.37 & & \\
\hline Sesquithujene & 1400 & & 0.11 & & 0.13 & 0.17 & 0.17 & & & & \\
\hline (E)-Caryophyllene & 1411 & & & & 0.07 & 0.1 & 0.14 & & & & \\
\hline$\gamma$-Elemene & 1427 & & & & & 0.07 & 0.54 & & & & \\
\hline$\alpha$-trans-Bergamotene & 1430 & & & & & 0.09 & 0.1 & & & & \\
\hline (E)-Isoeugenol & 1445 & & & & 0.12 & 0.1 & 0.19 & 0.75 & 1.08 & 1.12 & 1.21 \\
\hline$(E)-\beta$-Farnesene & 1453 & 0.57 & 0.82 & 0.48 & 0.75 & 0.95 & 1.04 & 0.47 & & & \\
\hline --Gurjunene & 1469 & & 0.34 & 0.2 & 0.27 & 0.37 & 0.6 & & & & \\
\hline$\gamma$-Muurolene & 1471 & & 0.16 & & 0.19 & 0.29 & 0.5 & & & & \\
\hline Germacrene D & 1474 & 1.32 & 1.73 & 1.38 & 1.86 & 1.85 & 1.28 & 1.47 & 1.11 & 1.35 & 1.31 \\
\hline ar-Curcumene & 1478 & 8.54 & 7.47 & 2.52 & 2.92 & 4.43 & 5.55 & 2.64 & 1.99 & 2.41 & 2.34 \\
\hline$\beta$-Selinene & 1486 & 0.97 & 1.16 & 0.78 & 1.04 & 1.3 & 1.53 & 0.92 & 0.71 & 0.84 & \\
\hline$\alpha$-Zingiberene & 1493 & 11.98 & 15.7 & 13.8 & 19.1 & 20.39 & 28.9 & 18.12 & 15.47 & 19.38 & 19.36 \\
\hline (Z)-a-Bisabolene & 1505 & 7.76 & 8.55 & 6.46 & 8.31 & 9.58 & 12.67 & 8.48 & 6.77 & 8.54 & 8.59 \\
\hline$\gamma$-Cadinene & 1510 & 0.77 & 0.89 & 0.73 & 0.52 & 0.49 & 0.52 & 0.56 & 0.57 & & \\
\hline$\beta$-Sesquiphellandrene & 1520 & 8.4 & 8.44 & 5.23 & 6.82 & 7.92 & 10.61 & 5.63 & 4.69 & 5.92 & 5.9 \\
\hline$(E)-\gamma$-Bisabolene & 1530 & 0.18 & 0.33 & 0.18 & 0.23 & 0.3 & 0.46 & & 0.31 & & \\
\hline (Z)-Calamenene & 1531 & 0.49 & 0.45 & 0.38 & 0.24 & 0.25 & 0.25 & & & & \\
\hline Hedycaryol & 1544 & 0.82 & 0.63 & 0.55 & 0.36 & 0.6 & 0.79 & & & & \\
\hline
\end{tabular}




\begin{tabular}{|c|c|c|c|c|c|c|c|c|c|c|c|}
\hline Germacrene B & 1549 & 1.39 & 0.66 & 1.05 & 0.9 & 0.77 & 0.34 & 0.88 & 0.88 & 0.95 & \\
\hline (E)-Nerolidol & 1560 & 2.18 & 1.75 & 1.4 & 1 & 1.02 & 0.99 & 0.57 & 0.58 & 0.6 & \\
\hline ar-Tumerol & 1575 & 0.34 & 0.31 & 0.19 & 0.09 & 0.1 & & & & & \\
\hline $\begin{array}{c}\text { Sesquisabinene } \\
\text { hydrate }\end{array}$ & 1585 & & & & 0.49 & 0.25 & & 0.73 & 0.95 & 0.98 & \\
\hline $\begin{array}{l}\text { 5-epi-7-epi-y- } \\
\text { Eudesmol }\end{array}$ & 1601 & & 0.39 & 0.26 & 0.16 & 0.17 & & & & & \\
\hline 10-epi- - -Eudesmol & 1613 & 0.61 & 2.33 & 0.46 & 0.32 & 0.4 & 0.33 & 0.69 & 0.98 & 1.11 & \\
\hline$\gamma$-Eudesmol & 1626 & 1.72 & 1.75 & 1.34 & 0.69 & 0.69 & 0.71 & 0.77 & 1.05 & 0.93 & \\
\hline epi-alpha-Murrolol & 1637 & & & & 0.26 & 0.17 & 0.78 & & & & \\
\hline$\beta$-Eudesmol & 1644 & 1.87 & 1.94 & 1.86 & 0.7 & 0.92 & 0.8 & 1.28 & 1.48 & 1.06 & 1.25 \\
\hline$\alpha$-Cadinol & 1649 & 1.4 & 1.19 & 1.22 & 0.41 & 0.21 & 1.52 & 0.79 & 0.67 & & \\
\hline$\beta$-Bisabolol & 1665 & & & & 0.09 & 0.49 & 0.58 & & & & \\
\hline Bisabolol $\alpha$ & 1684 & 3.58 & 2.96 & 3.05 & 0.13 & 0.14 & 0.13 & 1.54 & 2.19 & 2.22 & 2.15 \\
\hline (E.Z)-2.6-Farnesol & 1690 & 0.69 & 0.59 & 0.42 & 0.18 & 0.29 & 0.32 & & 0.4 & & \\
\hline (E.Z)-2.6-Farnesal & 1710 & & & & 0.34 & 0.26 & & & & & \\
\hline (E.Z)-2.6-Farnesol & 1717 & & & & 0.16 & 0.13 & 0.13 & & & & \\
\hline (E)-Nuciferal & 1722 & 0.46 & 0.37 & 0.2 & 0.09 & 0.09 & 0.11 & & & & \\
\hline (E.E)-2.6-Fanesal & 1737 & & 0.15 & 0.3 & 0.27 & 0.18 & 0.11 & & 0.35 & & \\
\hline Xanthorrhizol & 1750 & 0.28 & 0.23 & 0.12 & & & 0.09 & & & & \\
\hline (Z.Z)-Geranyl Linalool & 1951 & & 0.04 & & & & & & & & \\
\hline Hexadecanoic acid & 1958 & 0.8 & 0.79 & 0.63 & 0.12 & 0.24 & 0.15 & & & & \\
\hline Total identified & & 84.79 & 81.35 & 84.31 & 93.91 & 92.97 & 90.45 & 90.07 & 90.15 & 92.3 & 93.22 \\
\hline
\end{tabular}

1 - compounds identified by comparing their mass spectra and retention indices with Adams ${ }^{26}$ library

2 - IR retention index calculated in relation to a series of alkanes $\left(\mathrm{C}_{8}-\mathrm{C}_{20}\right)$

3 - Percentage area of each peak, according to the mass detector responses, in relation to the total area of the chromatogram considering response factor as 1 for all the compounds. 


\section{Principal Component Analysis (PCA)}

From the Principal Component Analysis, eight compounds stood out from the others, geraniol, neral, ar-curcumene, $\beta$-sesquiphellandrene, (Z)- $\alpha$-Bisabolene, $\beta$-Phellandrene, geranial and $\alpha$-zingiberene (Figure $5)$.

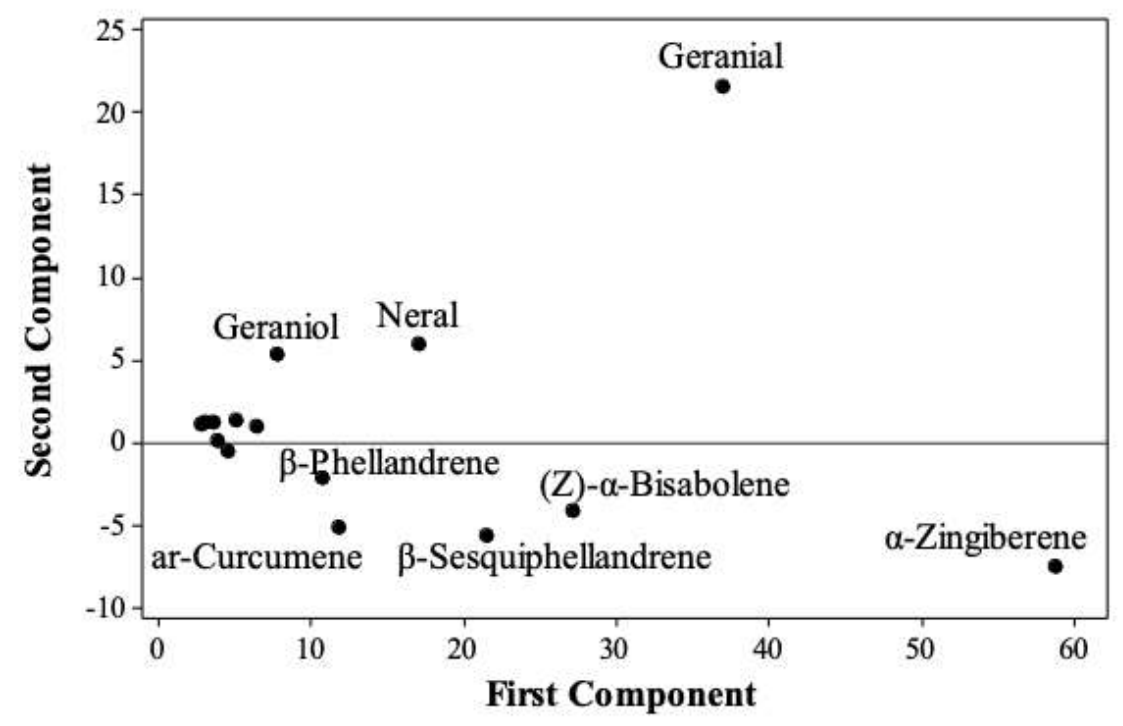

Figure 5. Variation behavior of the essential oil compounds of Zingiber officinale.

The PCA (Figure 6) was performed with the percentage obtained in the chromatographic analysis.

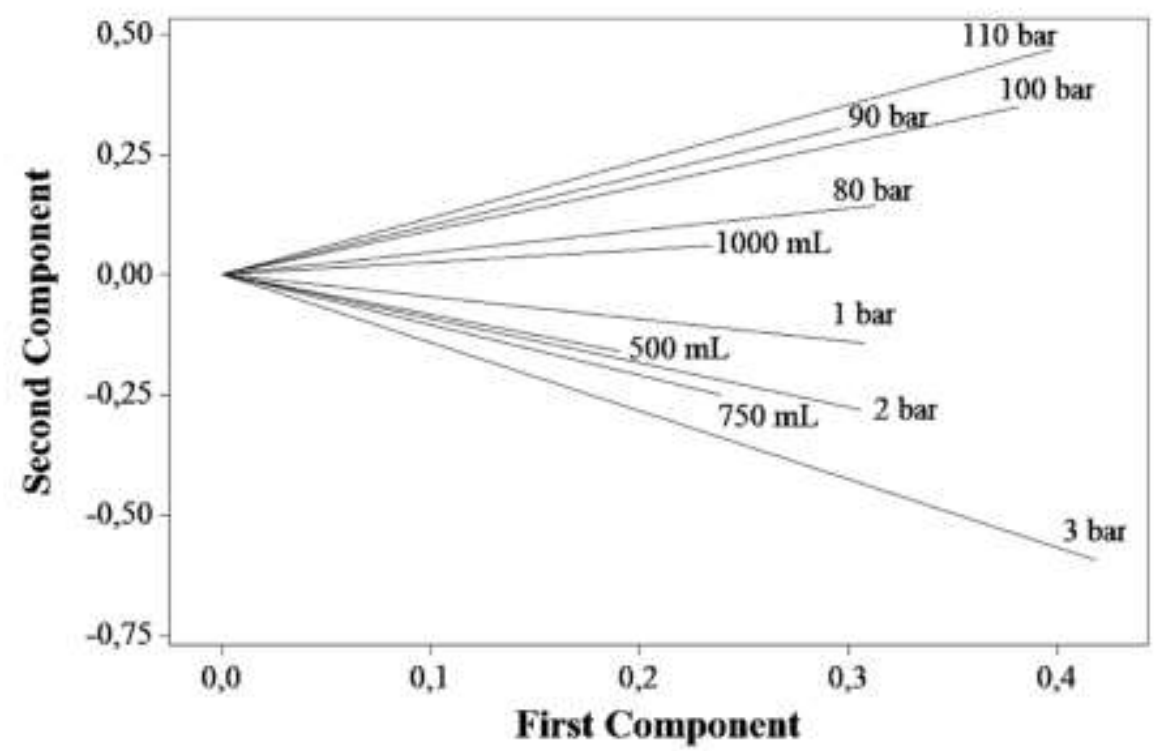

Figure 6. Variation behavior of the Zingiber officinale essential oil in relation to the different pressures and extraction methods.

\section{DISCUSSION}

\section{Mathematical modeling}

The determination coefficient corresponds to the adhesion of the model to the experimental data. For the three models the coefficient indicates that the models are suitable to fit the experimental extraction data. However, each model has a level of complexity, and thus, different applications. For a scale up the best 
model would be the Model 3, which allows modifications to the input variables and a series of additions like vessel geometry, bed porosity and solvent flowrate. In this way, the Model 3 could be used for further simulations with different equipment and scales.

\section{Principal Component Analysis (PCA)}

Since the constituents geranial and a-zingiberene presents the main composition areas, and it is observed that the variation between the techniques and conditions of percentage area is $1.33 \%$ to $25.05 \%$ and $28.9 \%$ to $11.9 \%$ respectively, their covariance in relation to the others is the greatest.

In Figure 5, which represents the behavior of the composition of the essential oil of Zingiber officinale related to the variation of the extraction pressure and the method of extraction, it is possible to observe the formation of four distinct groups. This clear division of the groups is attributed to the similarity of the percentage area of components obtained by GC-MS. The oil obtained by mean hydrodistillation presented a composition similar to the ones obtained by the steam distillation technique, which can be attributed to the similarity of these extraction methods, and therefore, in the PCA analysis, a similar behavior was observed for these two techniques.

The 3 bar SD condition presented the highest percentage of $\alpha$-zingiberene and $\beta$-sesquiphellandrene, however it scores low in the second component, indicating a lower amount of geranial and other major compounds such as neral and geraniol, it resembles to the other two SD conditions, but in a lesser degree. The HD for the $750 \mathrm{~mL}$ and $500 \mathrm{~mL}$ conditions has an analogous behavior to the SD, however the $1000 \mathrm{~mL}$ condition, due to the solubilization of polar compounds in reason to the water excess added, ends up having a greater percentage of less soluble compounds as geranial, and neral, due to a smaller total area of the chromatogram identified. The SFE obtained similar results in 80 and 90 bar and in 100 and 110 bar, with highest scores for the second component indicating a greater percentage of geranial and related compounds, while also marks high scores in the first component, indication high percentage values of a-zingiberene, however still lower than the SD for this component.

\section{CONCLUSION}

The Zingiber officinale essential oil was obtained through three different extraction methods. For SD and SFE methods, the experimental mass versus time curve was built for the highest yield condition. Three mathematical models, with different complexities, were used in order to simulate the extraction process and significant mass transfer parameters were fitted from the experimental data. All the samples were analyzed by GC/MS and statistically compared through a PCA. For the SD essential oil there are similarities between the 1 and 2 bar compositions. The SFE essential oil presented two similar groups, between 80 and 90 bar, and between 100 and 110 bar. The greatest values, in terms of composition, were 3 bar for $\alpha$-zingiberene in the steam distillation and 110 bar for geranial in supercritical fluid extraction and $1000 \mathrm{~mL}$ for geranial in hydrodistillation. The best conditions for SD, SFE and HD, in terms of yield, were 3 bar, 100 bar and $750 \mathrm{~mL}$. $\mathrm{HD}$ essential oil composition using $500 \mathrm{~mL}$ and $750 \mathrm{~mL}$ presented to be similar and through PCA is also possibile to observe a similarity with SD essential oil due to the similar principle of extraction.

Funding: This research was funded by Conselho Nacional de Desenvolvimento Científico e Tecnológico (CNPq), grant number 7621/2017-8.

Acknowledgments: The authors thank CNPq and CAPES.

\section{REFERENCES}

1. Salea R, Veriansyah B, Tijandrawinata RR. Optimization and scale-up process for supercritical fluids extraction of ginger oil from Zingiber officinale var. Amarum. The J. of Supercrit. Fluids. 2017 Feb;120:285-294.

2. FAOSTAT. Food and Agriculture Organization of the United Nations. Crops. 2016.

3. Young HY, Luo YL, Cheng HY, Hsieh WC, Liao JC. Peng WH. Analgesic anti-inflammatory activities of [6]-gingerol. J. Ethnopharmacol. 2005 Jan;96:207-210.

4. Mesomo MC, Corazza ML, Ndiaye PM, Dalla Santa OR, Cardozo L, Scheer AP. Supercritical CO2 extracts and essential oil of ginger (Zingiber officinale R.): chemical composition and antibacterial activity. J. Supercrit. Fluids. 2013 Aug;80:44-49.

5. Al-amin Z, Thomson M, Al-qattan K, Peltonen-shalaby R, Ali M. Anti-diabetic and hypolipidaemic properties of ginger (Zingiber officinale) in streptozotocin-induced diabetic rats. Br. J. of Nutr. 2006 Mar;96(4):660-666. 
6. Zeng HL, Han XA, Gu C, et al. Comparative protein analysis of K562 cell apoptosis induced by 6-gingerol. (J. of Chin. Med.). 2010 May;33:753-758.

7. Rhode J, Fogoros S, Zick S, et al. Ginger inhibits cell growth and modulates angiogenic factors in ovarian cancer cells. BMC Complement. Altern. Med. 2007 Dec;20:44-51.

8. Weng CJ, Wu CF, Huang HW, Ho CT, Yen GC. Anti-invasion effects of 6-shogaol and 6-gingerol two active components in ginger. on human hepatocarcinoma cells. Mol. Nutr. Food Res. 2010 Nov;54:1618-1627.

9. Nigam N, George J, Srivastava S, et al. Induction of apoptosis by [6]-gingerol associated with the modulation of p53 and involvement of mitochondrial signaling pathway in $\mathrm{B}[\mathrm{a}] \mathrm{P}$-induced mouse skin tumorigenesis. Cancer Chemother. Pharmacol. 2010 Mar;65:687-696.

10. Mesomo, Michele Cristiane. (Ginger extract obtation using spercritical $\mathrm{CO}_{2}$ and compressed propane: knetics of extraction and biological activity) (Zingiber officinale Roscoe) [dissertation]. Curitiba (PR): Federal University of Paraná; 2013. 77 p.

11. Barros FMC, Almeida PC, Scopel R, et al. Chromenes from Ageratum conyzoides: steam distillation. supercritical extraction and mathematical modeling. Sep. Sci. and Technol. 2016 Aug;51:307-315.

12. Cassel E, Vargas RMF, Martinez N, Lorenzo D, Dellacassa E. Steam distillation modeling for essential oil extraction process. Ind. Crop. and Prod. 2009 Jan;29:171-176.

13. Barroso MST, Villanueva G, Lucas AM, Perez GP, Vargas RMF, Brun GW, Cassel E. Supercritical fluid extraction of volatile and non-volatile compounds from Schinus molle L. Braz. J. Chem. Eng. 2011 Jun;28:305-312.

14. Shukla A, Naik SN, Goud VV, Das C. Supercritical CO2 extraction and online fractionation of dry ginger for production of high-quality volatile oil and gingerols enriched oleoresin. Ind. Crops and Prod. 2019 Apr;130:352362.

15. Chen Y, Zhang C, Zhang M, Fu X. Three statistical experimental designs for enhancing yield of active compounds from herbal medicines and anti motion sickness bioactivity. Pharmacogn. Mag. 2015 Sep;1:435-443.

16. Sohpal VK. Comparative analysis of Supercritical fluid extraction and Solvent extraction for Zingiber officinale aromatic compounds. Res. J. of Chem. and Environ. 2018;22:64-71.

17. Lucas, Aline Machado. (Comparative study of eucalypt volatile extracts of genetic modified and non-genetic modified eucalypt) [dissertation]. Porto alegre (RS): Pontifícal University Catholic of Rio Grande do Sul; 2011. 76 p.

18. Dagostin JLA, Carpiné D, Corazza ML. Extraction of soybean oil using ethanol and mixtures with alkyl esters (biodiesel) as a co-solvent: Kinetics and thermodynamics. Ind. Crops and Prod. 2015 Nov;74:69-75.

19. Crank J. The Mathematics of Diffusion. 2nd ed. London: Oxford University Press; 1975. 414 p.

20. Almeida RN, Neto RG, Barros FMC, Cassel E, Poser GL, Vargas RMF. Supercritical extraction of Hypericum caprifoliatum using carbon dioxide and ethanol + water as co- solvent. Chem. Eng. and Process.: Process intensif. 2013 Aug;70:95-102.

21. Cargnin ST, Nunes JM, Haas JS, et al. Supercritical fluid extraction and high-performance liquid chromatographic determination of benzopyrans and phloroglucinol derivative in Hypericum polyanthemum. J. of Chromatogr. B. 2010 Jan;878:83-87.

22. Scopel R, Silva CF, Lucas AM, et al. Fluid phase equilibria and mass transfer studies applied to supercritical fluid extraction of Illicium verum volatile oil. Fluid Ph. Equilib. 2016 Jun;417:203-211.

23. Scopel R, Falcão MA, Lucas AM, et al. Supercritical fluid extraction from Syzygium aromaticum buds: Phase equilibrium. mathematical modeling and antimicrobial activity. The J. of Supercrit. Fluids. 2014 Aug;92:223-230.

24. Garcez JJ, Barros F, Lucas AM, et al. Evaluation and mathematical modeling of processing variables for a supercritical fluid extraction of aromatic compunds from Anethum graveolens. Ind. Crops and Prod. 2017 Jan;95:733-741.

25. Sauter IP, Rossa GE, Lucas AM, et al. Chemical composition and amoebicidal activity of Piper hispidinervum (Piperaceae) essential oil. Ind. Crops Prod. 2012 Nov;40:292-295.

26. Adams RP. Identification of essential oil components by gás chromatography / mass spectrometry. 4nd ed. Illinois: Allure; 2007. $804 \mathrm{p}$.

27. Reverchon E. Mathematical modelling of supercritical extraction of sage oil. AIChE J.1996 Jun;42:1765-1771.

28. Sartor RB, Secchi AR, Soares RP, Cassel E. Dynamic simulation of rosemary essential oil extraction in an industrial steam distillation unit. Ind. and Eng. Chem. Res. 2011 Mar;50:3955-3959. 
29. Toure A, Xiaoming Z. Gas Chromatographic Analysis of Volatile Components of Guinean and Chinese Ginger Oils (Zingiber officinale) Extracted by Steam Distillation. J. of Agron. 2007;6(2):350-355.

CC) (5) 2020 by the authors. Submitted for possible open access publication under the terms and
conditions of the Creative Commons Attribution (CC BY NC) license
(https://creativecommons.org/licenses/by-nc/4.0/). 